Discussion Paper No. 02-27

\title{
The Benefits of Creating an Integrated EU Market for Investment Funds
}

Friedrich Heinemann

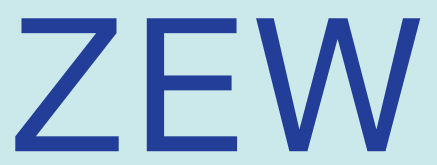

Zentrum für Europäische Wirtschaftsforschung GmbH

Centre for European Economic Research 
Discussion Paper No. 02-27

\title{
The Benefits of Creating an Integrated EU Market for Investment Funds
}

\author{
Friedrich Heinemann
}

Download this ZEW Discussion Paper from our ftp server:

\begin{abstract}
ftp://ftp.zew.de/pub/zew-docs/dp/dp0227.pdf
\end{abstract}
Die Discussion Papers dienen einer möglichst schnellen Verbreitung von neueren Forschungsarbeiten des ZEW. Die Beiträge liegen in alleiniger Verantwortung der Autoren und stellen nicht notwendigerweise die Meinung des ZEW dar.

Discussion Papers are intended to make results of ZEW research promptly available to other economists in order to encourage discussion and suggestions for revisions. The authors are solely responsible for the contents which do not necessarily represent the opinion of the ZEW. 


\section{Non-technical Summary}

The fast growing EU market for investment funds is still characterised by a continuing relevance of national borders. This papers assesses this market's degree of integration, the potential benefits from more integration and the obstacles to cross-border sales of funds.

Data on cross-border registration of funds seem to indicate a high level of integration: At least in the big markets there are thousands of registered foreign funds. However, these so called foreign funds are by far dominated by funds domiciled in Luxembourg, Dublin or other tax preference location. Although these funds are cross-border in a formal sense they are mostly designed for a particular national market by suppliers of the same country while the choice of the domicile results from tax reasons. Real foreign funds still have only a minor market share. Thus, national markets are still largely dominated by the domestic suppliers. Further results in regard to the status quo of fund market integration are: Product availability is severely restricted in the smaller European countries where investors have only the choice among a few hundred fund products. Furthermore, many national fund industries do practically not export their domestic funds. This is a worrying result since these products are not tested in international markets.

The quantification of potential benefits of increasing integration is based on a economies of scale consideration. As a consequence of national fragmentation, on average, European funds are considerably smaller than US funds. Fund size, however, is a significant driving force for average management costs. Here, a thorough study of the US Securities Exchange Commission on fund costs determinants lays the basis for some scenario calculations. These scenario calculations are helpful to quantify the cost saving potential in the European fund industry assuming an increasing average asset size per fund.

The analysis goes on by identifying the relevant obstacles that explain the imperfect integration. These obstacles are related to the European legislative process, the fund registration procedure, the host country responsibility for advertising and marketing, tax discrimination practices and the characteristics of the existing distribution channels. 


\title{
The Benefits of Creating an Integrated EU Market for Investment Funds
}

\author{
Friedrich Heinemann \\ Zentrum für Europäische Wirtschaftsforschung (ZEW)
}

April 2002

\begin{abstract}
The fast growing EU market for investment funds is still characterised by a continuing relevance of national borders. This papers assesses this market's degree of integration, the potential benefits from more integration and the obstacles to cross-border sales of funds. The analysis shows that markets of small member countries are particularly isolated since for suppliers of funds the market potential is too small to compensate for the fixed costs of market entry. But also in the big markets foreign funds lack market success. A better integrated European market for investment funds would provide three kinds of benefits: It increases choice of products, it allows to realise economies of scale and it intensifies competition for the benefit of private investors. It is argued that the present characteristics of fund distribution channels are mainly responsible for fragmentation besides regulatory and tax issues.
\end{abstract}

JEL-Classification: G 23, G 38

Keywords: UCITS, investment fund, European integration

\section{Acknowledgement:}

The author gratefully acknowledges financial support from the European Financial Services Roundtable, Brussels. He is also indebted to Diana Mackay, European Fund Information Services, London, for providing data on cross-border notifications of European investment funds.

L 7, 1

P.O. Box 103443

D-68034 Mannheim
Phone: $\quad 0621 / 1235-149$

Fax: $\quad 0621 / 1235-223$

E-mail: heinemann@zew.de 


\section{Introduction}

The European investment fund industry is looking back at a period of high growth. Assets of European UCITS $^{1}$ almost tripled from 1.21 trillion Euros by end 1995 to 3.56 trillion by end 2000 (see figure 1). In the same period the ratio of European investment funds (UCITS and other types) assets relative to GDP has grown from $23 \%$ to $52 \%$. On a per capita basis this represents a growth of 4,000 Euro in 1995 to 11,600 Euro in $2000 .^{2}$ Even in the depressive phase at the stock exchanges in the first half of 2001 the industry proved its robustness - and could still realise a moderate positive growth rate of 2\% in terms of UCITS' net assets (FEFSI, 2001b).

\section{Figure 1: Data on the European Market for UCITS}
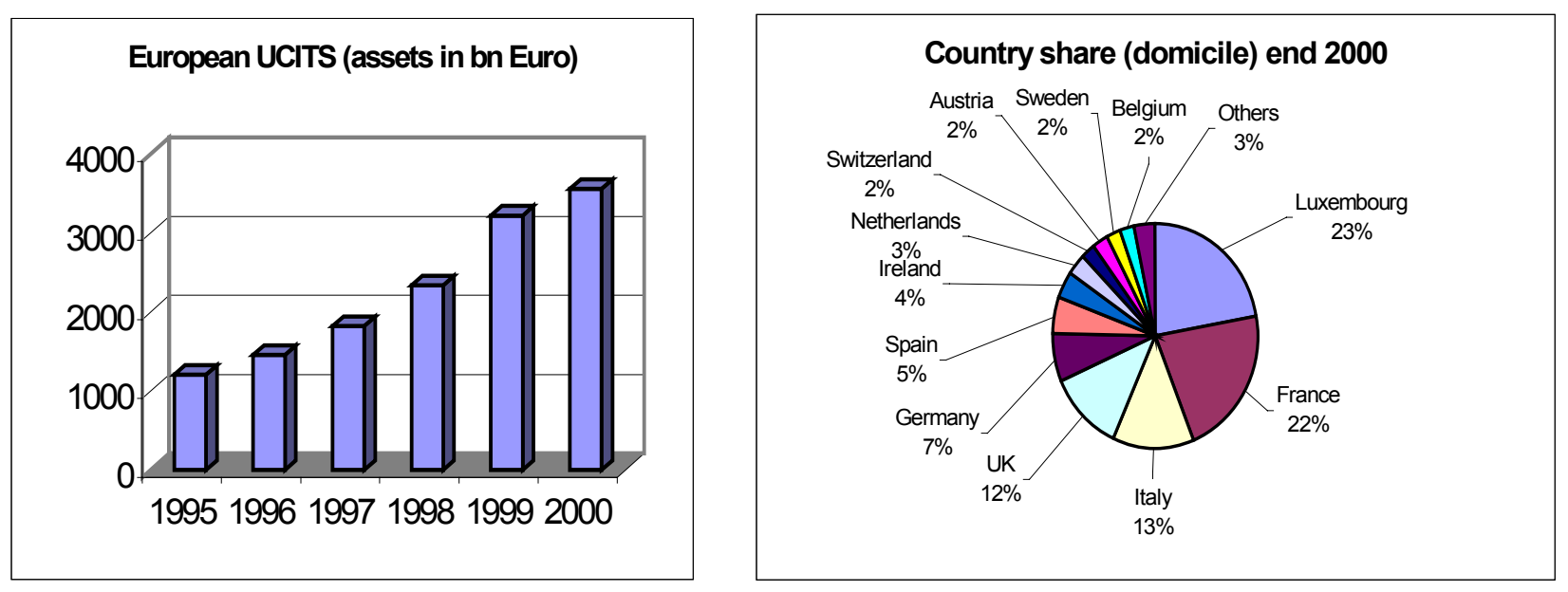

Source: FEFSI (2001). German special funds (set up for institutional investors, not sold to the public) not included. Together with special funds the German share comes close to that of France and Luxembourg.

In spite of the recent growth slowdown the long-run potential remains high. The fund industry is going to benefit from stable trends like the shift of savings towards more sophisticated capital market products and the need for long-run capital formation of an ageing population.

While the growth rates seem to suggest a smooth development of the sector, there remains one major shortcoming: The EU market for investment funds is not a EU

1 UCITS stands for "undertakings for collective investment in transferable securities" as defined in the Directive 85/611/EEC which was to establish the internal market for investment funds.

2 All data are from FEFSI (2001). Note that FEFSI reports aggregate data for its member countries which in addition to EU countries include Switzerland, Norway, Czech Republic, Hungary and Poland. 
market in the true sense. National markets so far remain highly dominated by domestic fund companies. The reasons for the fragmentation are not obvious given the fact that important regulatory measures to open the markets date back to 1985 when the UCITS directive took effect.

The lasting relevance of national borders is less easy to understand compared to other financial services like credit or insurance where obvious information problems hinder cross-border sales. Information problems seem not to be that relevant for open end funds: Fund rankings by companies like Standard \& Poor's are easily accessible and provide comparisons in regard to the quality of domestic and foreign products.

National fragmentation is costly. It restricts choice of consumers to the products of the national market. Competition is less intense than it would be with a truly unified market. In addition, disadvantages arise from small average fund size in EU countries compared to the US. Since substantial cost shares of running a fund (advertising, research, accounting and legal obligations) have a fixed character, an increasing size of assets opens leeway for falling relative operating costs. Because in the present situation, similar fund products can not be pooled for all EU countries but have to be set up in national variants, these economies of scale can not be realised. An increasing integration would therefore benefit consumers through a triple effect. First, choice would increase. Second, average fund sizes could grow leading to economies of scale. Third, the increasing competitive pressure should shift a major part of these costs savings towards consumers.

It is the purpose of this study to quantify the corresponding potential benefits for European fund investors and to contribute to a better understanding of integration obstacles. For that purpose, it is made extensive use of a thorough study on the determinants of fund expenses executed by the Securities Exchange Commission in 2000 based on a large sample of US funds.

The analysis proceeds the following way. Section 2 describes recent trends for the EU fund industry concerning size, growth and integration. Section 3 presents results on potential costs savings through an increase in average fund size. Section 4 looks into the present obstacles to further integration. Section 5 concludes by assessing priorities for regulators and the industry itself to overcome the fragmentation.

\section{EU fund industry: borders matter}

The growth of the EU fund industry should not obscure the fact that the market is far from being a unified market. Assessing the degree of integration, a two-step approach is helpful. For a successful cross-border marketing of funds two kind of hurdles have to be overcome: 
- First, the regulatory obligations need to be fulfilled by registering a fund with the authorities in the target market (type one integration). ${ }^{3}$

- Second, market success has to follow. The fund has to find investors in the target market willing to shift money from domestic to foreign funds (type two integration).

Integration of type one (notification procedure) is a necessary but not a sufficient condition for type two integration (market success). The data base to assess type one integration is much better than for type two. Data on number of cross-border fund notifications obtained from European Fund Information Services, London, allow at least a rough quantification to which extent the notification hurdle is overcome. Data on the market success of foreign funds are not available on such a consistent basis.

Figure 2 shows for each country the number of funds notified and the domicile of these funds. At the first view, the data seem to indicate that type one integration of European fund markets is large since in most countries (exception Denmark, France and Spain) there are more foreign than domestic funds available. However, this is an incomplete picture. Foreign funds are by far dominated by funds domiciled in Luxemburg, Dublin and other tax preference locations. These funds often are of the "round trip" type: although being cross-border in a formal sense they are designed for a particular national market and the choice of the domicile results from tax reasons.

The figure immediately reveals a particular type of fragmentation costs carried by consumers in small European countries. These investors suffer from a lack of choice among products. While investors in big markets can choose among thousands of products, availability is restricted to a few hundred in countries like Denmark, Greece, Portugal and Norway.

3 A fund fulfilling the UCITS definition must be accepted by each EU supervisory authority. Nevertheless, the notification procedure can be costly and time consuming - see section 4 . 
Figure 2: Number of funds available in national markets (31 March 2001)

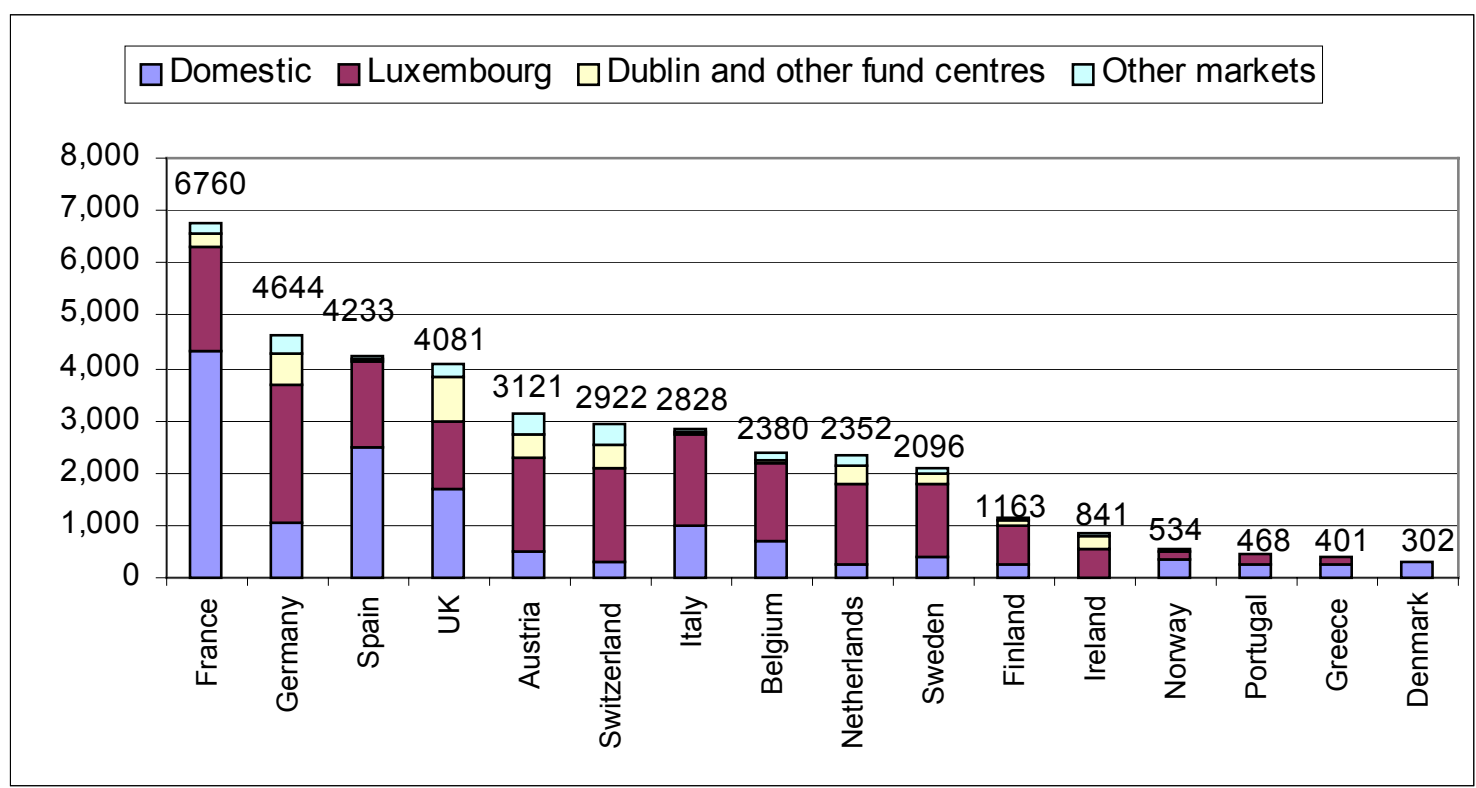

Source: European Fund Information Service, London, derived from Lipper data The category Dublin and other fund centres includes the Channel Islands, Bermuda, Liechtenstein and the Netherland Antilles.

The national fragmentation of markets also becomes obvious by asking:

- to how many EU countries are domestic funds being exported and

- from how many EU countries are funds imported?

Figure 3 counts the number of import and export markets from the perspective of each EU country. There are only three countries - Luxembourg, Ireland and the UK - whose funds are sold at least in two third of all member countries. Many national fund industries do practically not export their domestic funds. In no EU country there are today funds available from more than 6 other EU domiciles. While this finding may partly be influence by the Luxembourg effect - beneficial tax domiciles are used for cross-border funds - these findings nevertheless show the closeness of national markets.

So far the analysis was solely based on data in regard to step one of cross-border strategy, i.e. the existence of a cross-border notification. However, a notification with the target market's authorities does not guarantee market success. A matrix on EU market penetration of cross-border funds is not available. Fund management groups treat this kind of information as secret. 
Figure 3: Inward and outward openness of EU countries' fund sectors

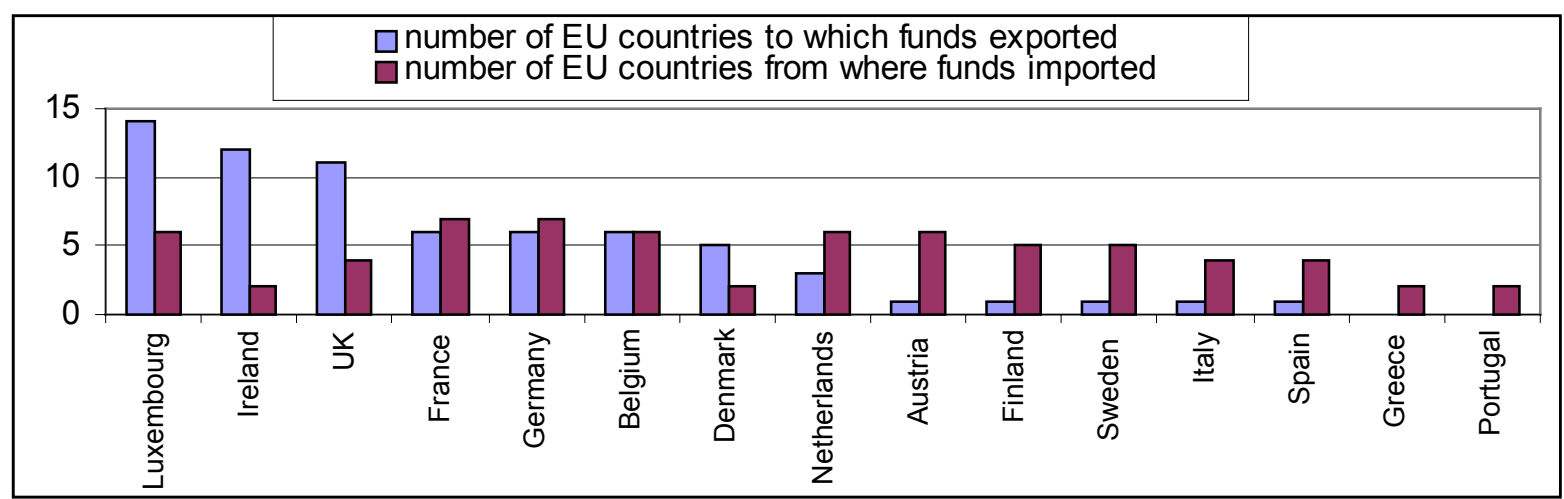

Source: Calculations based on matrix of cross-border notifications from European Fund Services, derived from Lipper data. An import/export relationship between two EU countries is counted if there are at least 5 fund notifications in a field.

Data on foreign funds market shares as published in different research material are not consistent. In an unpublished paper of summer 2001, European Fund Services estimates the market share of pure foreign funds (round-trippers are excluded) in Germany for mid 2000 at a level of around 13\% in terms of assets. Foreign market shares in France, Italy and Spain are estimated to be not higher than 5\% in the same source. In Sweden, foreign funds' market share is reported to be even below $1 \%$. MoODY's (2000) estimates the market share of foreign funds in Germany with $2.4 \%$ of assets much lower and with $7.6 \%$ for Italy a bit higher. Even these contradicting bits of information clearly show that the large shares of foreign funds in nationally registered products (see figure 3) is by far no indicator for market shares. All available asset based data show that true foreign funds still play nothing but a minor role.

\section{Quantifying potential economies of scales}

On average funds domiciled in the EU are much smaller than US funds: While in the end of the first quarter 2001 a typical EU fund possesses assets of 176 million Euro ${ }^{4}$, the average US size is with 910 million Euro five times larger. Fund size differs considerably between EU countries (see figure 4) - the extremes are Italy with 417 million and Finland with only 56 million.

\footnotetext{
${ }^{4}$ FEFSI reports for the end of 2000 even a larger discrepancy: an average of 140 million Euro for a European and 875 million Euro for a US fund. These FEFSI calculations include, however, also funds from non-EU European countries.
} 


\section{Figure 4: Average fund size (million Euro, end of March 2001)}

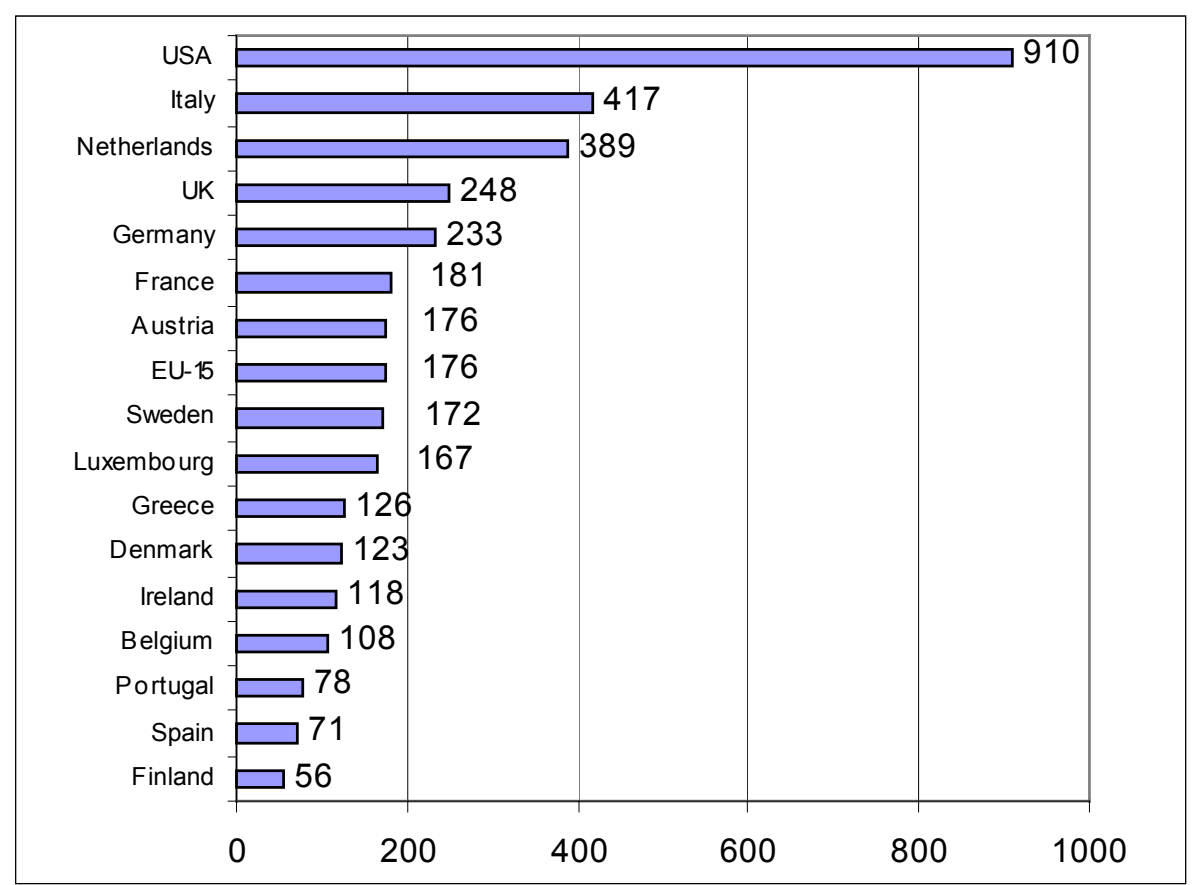

Own calculation based on fund asset data by FEFSI and data on number of funds by European Fund Service derived from Lipper data. Included are only publicly offered, open-ended funds. A fund is attributed to the country of domicile independent from where it is sold.

The smaller European size is an obvious consequence of market fragmentation. If borders did not play a role in selling funds, average fund size and country size should not be correlated as they obviously are. With separation of markets, a national product is largely restricted to national consumers, implying the correlation between country and fund size.

Fund size is a significant driving force for average costs. This intuitively appealing hypothesis was supported by a thorough study of the US Securities Exchange Commission in 2000 (SEC, 2000). Based on 1999 data for almost 9000 funds the study explores the determinants of fund costs. ${ }^{5}$ Included in these expenses are management fees, but not sales loads and no transaction costs for a fund's selling and buying of securities. ${ }^{6}$

5 Money market funds are excluded from the database.

6 The reason for excluding sales loads results from data problems: For a sensible integration of these costs on an annual basis one would need to know average holding periods for each fund. Apart from that data on effectively paid sales load are not obtainable. The exclusion of sales load should not bias the SEC analysis' results too much since the basic regression includes a dummy for load/ no-load funds. 
Figure 5: Fund expense ratio in \% depending on size of assets

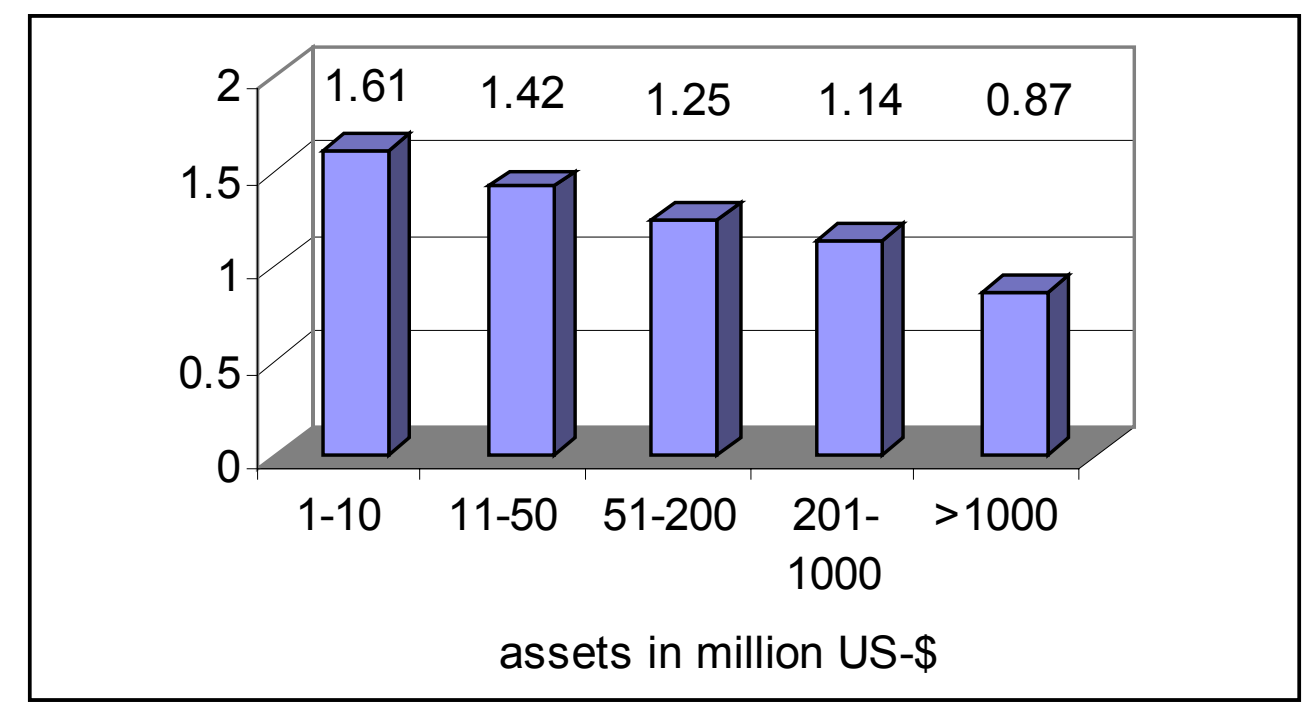

Source: SEC (2000), data base: 9000 open-ended US funds, without money market funds. Expense ratio does not include sales loads.

While the descriptive view already reveals a negative correlation between volume of assets and expenses (see figure 5), this finding alone would not provide a robust basis for the analysis, since a multitude of determinants explain the costs of running a fund and could bias the results: Equity funds are more expensive than bond funds. Funds investing in domestic assets are cheaper than internationally investing funds etc. More reliable than the simple descriptive view are therefore the results of a multivariate regression.

Such a cross section regression is included in SEC (2000). Among others the following control variables are included in the specification: volume of fund assets, portfolio turnover, fund age and several dummies for fund category (equity, bond, specialty, international), index and no-load funds. A crucial result for the purpose of this paper is: the volume of a fund's assets turn out to have a highly significant negative impact on fund expenses. Figure 6 depicts the economies of scales associated with these regression coefficient. It shows that ceteris paribus a 10/50/100 million $\$$ fund has a cost disadvantage compared to a 1 billion $\$$ fund of $44 / 28 / 22$ basis points.

Since a study of a comparable data base and quality does not exist for the European fund industry, these US findings are the best available basis for a quantification of the potential benefits from larger European fund sizes. Of course, cost structure of US and EU fund sector are not completely identical due to differences in regulation, competition and investors' preferences. Nevertheless, the assumption seems well justified that basic features of the cost structure are comparable between both markets. 
Figure 6: Cost disadvantage to fund size of 1 billion US-\$ (in basis points)

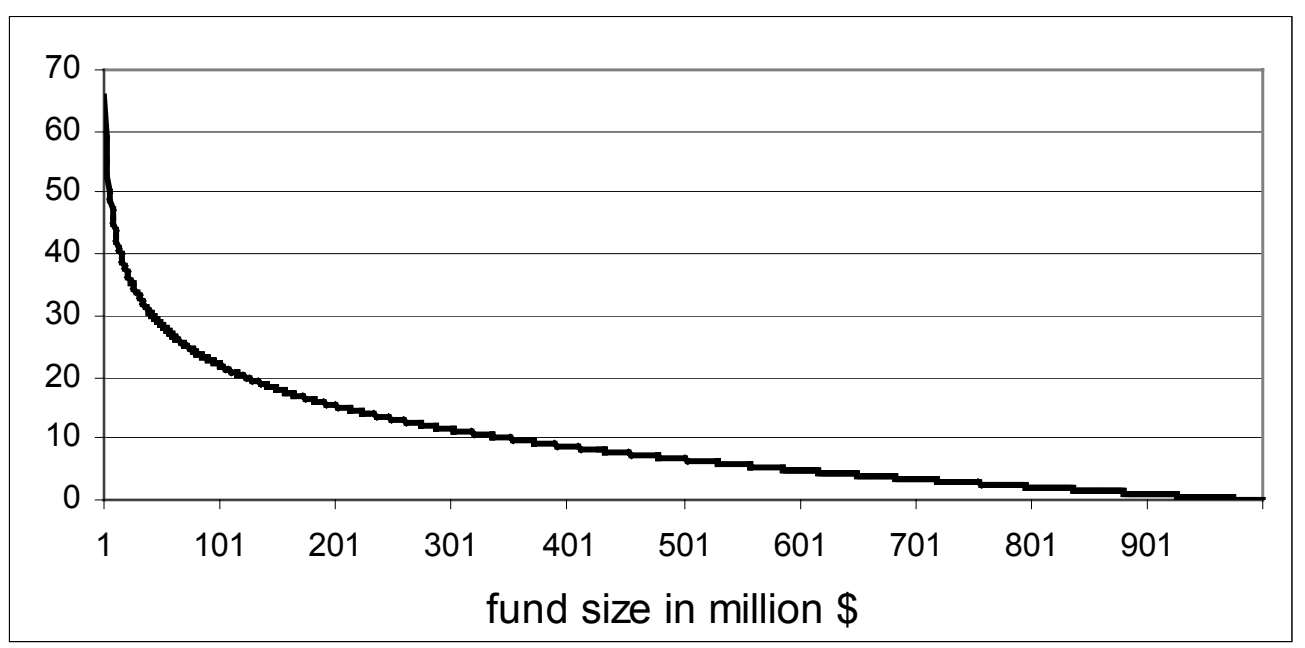

Calculated from regression results in SEC (2000). The underlying relationship between fund size and costs holds ceteris paribus, i.e. for the comparison of two funds where all other cost driving determinants are identical.

The assessment of the cost savings potential through pooling of funds in a unified EU fund market comes to interesting results. In the logic of the economies to scale argument, consumers in those countries with the smallest funds today could expect the largest benefits from European fund pooling. Figure 7 shows the potential savings in basis points for different EU markets for different scenarios on average fund size. The 400/600/800 million $\$$ scenario assumes that average EU fund size reaches half/three quarters/total of the present US level.

\section{Figure 7: Cost savings under different fund size scenarios (in basis points)}

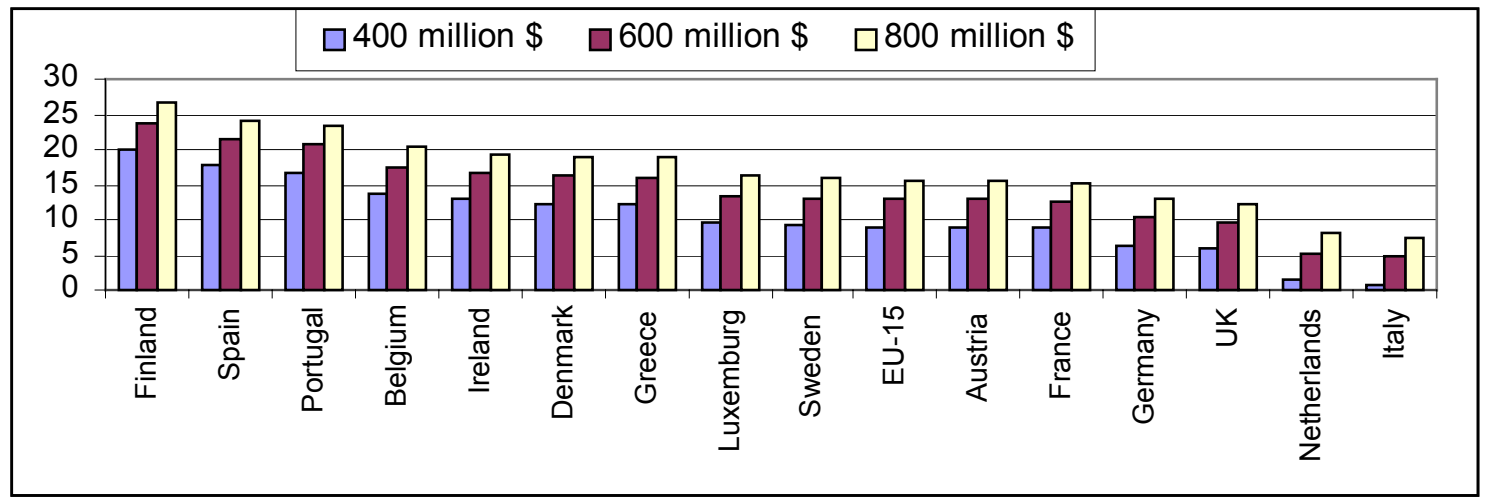

Calculations based on regression results from SEC (2000). Note that country assignment refers to domicile of funds. Particularly in the cases of Ireland and Luxembourg this is not equivalent to target market of funds. 
The cost savings associated with these scenarios are not trivial in absolute numbers. Figure 8 gives an indication based on the present size of the EU fund sector and the above quantified economies of scale: Annual costs of managing European funds could be cut by around five billion Euro if the average US fund size could be realised (which is about 800 million \$). Of course, these numbers can only be regarded as a rough indication of benefits. One major shortcoming is the static perspective of the analysis that is based on the present size of European fund markets. Even under the present fragmentation and inefficient cost structure this financial segment is growing. If efficiency gains through pooling could be realised this should lead to a further acceleration of growth. In this sense these benefit estimates can be regarded as conservative.

There is no reliable way to quantify how these cost savings would be distributed between the industry (profit margin increase) and the private investors (increase in net returns). Since integration of fund markets would lead to an intensification of competition among fund companies the chances should not be bad for investors to gain a significant part of these cost savings.

It should also be pointed out that another dimension of benefits from pooling EU funds does not shine up in these data: the larger choice for investors from small EU countries if most funds were sold pan-European.

Figure 8: Potential annual savings of fund expenses in EU (in million Euro)

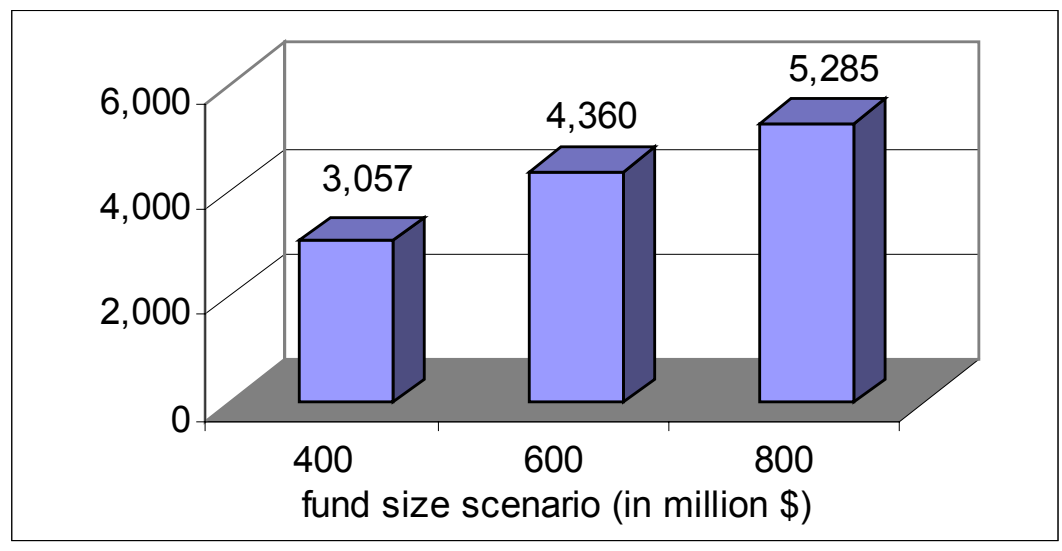

Calculation based on FEFSI data on the size of EU fund markets end of March 2001, assumption is that economies to scale correspond to the findings of SEC (2000).

\section{Obstacles to cross-border sales of funds}

Based on the above analysis there can be no doubt that a unified EU fund market would be beneficial for consumers. In contrast to that finding it is less obvious how this aim can best be reached. Although many obstacles have been identified it is far from clear which of these obstacles are most important. For purposes of analytical 
stringency, a basic distinction should be made between "policy induced" and "natural" obstacles. Policy induced hurdles to cross-border sales of funds can directly be dismantled by appropriate adjustments of EU and national legislation. Natural obstacles resulting from consumers preferences or the inherent characteristics of a market are not under the direct control of policy makers. It should be stressed that "natural" as used here is not to be understood as unalterable. It might be the case that market trends or changes in consumer behaviour tend to overcome existing "natural" obstacles.

\subsection{Policy-induced obstacles: regulation and taxation}

The fund industry itself as represented by its European association FEFSI or the US counterpart ICI stresses very much the importance of the policy-induced obstacles. This analysis can be summarised in the following way: ${ }^{7}$

Although the UCITS Directive in 1985 intended to provide a convenient passport for pan-European sales of funds its success remained so far limited. Reasons are:

Innovations leaving UCITS definition outdated: The European fund passport is limited to those products fulfilling the Directive's definition of UCITS. Here the legislator always lags behind market development. Examples concern money market funds, "funds of funds" or certain index funds (those that conflict with the issuer ceilings, Herring, 2001) that so far have not been included in the UCITS definition.

The burden of registration in the target market: The UCITS Directive is interpreted and implemented differently in member states. According to the Directive a fund must be authorised for sale by local authorities in the target market. Registration procedures are nationally different. ICI (2000) reports for example that in Italy registration takes typically up to six months. Further examples highlight the burden of the diffuse registration procedures (Moody's, 2000): In Spain an official translation of the fund prospectus is obligatory. The Netherlands require a detailed tax history of a fund.

Host country responsibility for advertisement and marketing: Article 44 (2) of Council Directive 85/611/EEC of 20 December 1985 (last amendment from November 2000) states: "Any UCITS may advertise its units in the Member State in which they are marketed. It must comply the provisions governing advertising in that State." Thus one single pan-European marketing strategy for a fund is impossible due to different national restrictions for this strategy.

Tax discrimination of foreign funds: In a multitude of ways national tax laws discriminate against foreign funds (FEFSI AND PRICEWATERHOUSE COOPERS, 2001). An extreme example is Denmark where a discriminatory taxation of

7 For a recent summary of these associations' views see FEFSI (2001c) and ICI (2000) 
capital gains of foreign funds practically precludes the market entry of foreign funds (see table 1 for details). Fortunately, in many countries tax discriminations are of a milder nature for foreign funds that are registered.

Table 1: Significant discriminatory tax barriers to the sale of foreign UCITS in their territory

\begin{tabular}{|c|c|}
\hline Country & $\begin{array}{l}\text { Description of discriminatory tax } \\
\text { measure }\end{array}$ \\
\hline Austria & Existing income tax regime \\
\hline Belgium & $\begin{array}{ll}\text { i. } & \text { Tax on distributions to individual } \\
\text { ii. } & \text { Participation exemption } \\
\text { iii. } & \text { Benefit from foreign tax credits }\end{array}$ \\
\hline Denmark & Foreign fund legislation \\
\hline Finland & none noted \\
\hline France & i. Plan d'Epargne en Actions ('PEA') \\
\hline Germany & $\begin{array}{ll}\text { i. } & \text { Existing foreign investment fund } \\
& \text { law } \\
\text { ii. } & \text { New tax reform measures }\end{array}$ \\
\hline Greece & $\begin{array}{l}\text { Investment funds legislation which } \\
\text { penalises foreign UCITS }\end{array}$ \\
\hline Ireland & $\begin{array}{l}\text { Taxation of Irish investors in offshore } \\
\text { UCITS }\end{array}$ \\
\hline Italy & Capital gains tax \\
\hline Luxembourg & None noted \\
\hline Netherlands & Reclaim of foreign withholding tax \\
\hline Portugal & $\begin{array}{l}\text { Different income tax regimes for } \\
\text { individual investors }\end{array}$ \\
\hline Spain & None noted \\
\hline Sweden & None noted \\
\hline UK & $\begin{array}{ll}\text { i. } & \text { Offshore fund legislation } \\
\text { ii. } & \text { UK Imputation tax system }\end{array}$ \\
\hline
\end{tabular}

Source: FEFSI/PRICEWATERHOUSE COOPERS (2001), p. 15, including all tax law changes up to April 2001.

From a fund company's perspective, the registration and advertising related obstacles lead to a fixed cost problem for entering a new EU target market. These fixed costs will make an entry only profitable if there is sufficient potential in the target country. The findings on cross-border notifications in section 2 are consistent with this view. Foreign funds are much more present in the big fund markets. 
Attempts to simplify entry costs would therefore be particularly promising for opening up the markets of the smaller countries.

It is, however, questionable whether even the best regulatory changes could really produce a fast integration of fund markets. The experience of markets like Germany or France poses some challenging questions: Here the significant presence of foreign funds prove that the fixed cost problem is of less relevance for these markets. Thousands of foreign funds have overcome the registration and advertisement hurdles but their market success is limited. Explanation attempts must therefore also look at the natural barriers.

\subsection{Natural obstacles: consumer preferences and the features of existing distribution channels}

A natural obstacle to cross-border sales of funds in Europe could result from consumer preferences. It is, however, doubtful whether consumers really have a preference for investment funds from domestic companies. According to research cited by MACKAY (2001) the criterion fund performance is today a top criterion in fund selection while much less interest is paid to the domicile of a fund. In addition, ranking lists of fund performance are today easily available through the Internet and these rankings include registered foreign funds. Thus it is hard to explain the present pattern of the market from consumer preferences or information problems alone factors that may play a larger role for other financial services.

MoODY's (2000) convincingly assigns large importance to a further natural obstacle resulting from the existing distribution channels. Still the major part of funds is sold over the bank counter. Banks still often advise their customers with a bias towards fund products of the own group. Therefore, foreign funds still lack distributive capacities preventing a breakthrough even after overcoming the regulatory hurdles of the registration procedure.

The distribution obstacle is natural in the sense that legislators do not have direct instruments to overcome it. However, ongoing market trends can be expected to alleviate the problem in the future.

First, the expected restructuring of distribution channels towards direct internet sales and independent fund shops ("fund supermarkets") will work towards structures less biased towards domestic products (see figure 9). These newly emerging channels operate on the 'open architecture' approach where distributors offer other groups' funds to their clients (WARLAND, 2002). Second, as a by-product of cross-border M\&As in banking the domestic bias in this sector is being reduced. Third, the bias for domestic funds might also decline within domestic banks. Consumer sophistication is increasingly pushing the demand for third party products. Banks have to react and to offer a more neutral assistance in fund selection or otherwise risk to lose market share. 


\section{Figure 9: Dominating Fund Distribution Channels for the German Market 1998 and 2005 Forecast}
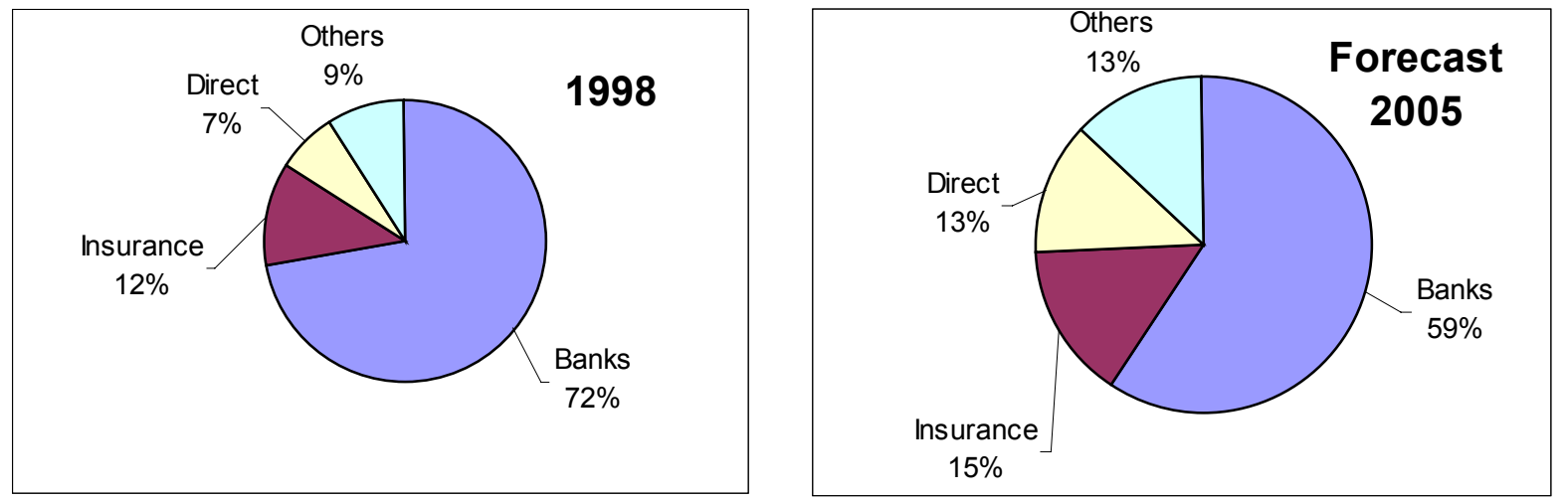

Source: Bundesverband Deutscher Investmentgesellschaften

\section{Policy priorities}

Even if market trends will successfully open the big EU countries for foreign funds this will not help the smaller countries to the same extent. Here the limited market potential will prevent foreign suppliers from paying the "entrance ticket" in form of the costly registration procedure. Therefore it is of particular importance for the smaller markets that the policy-induced obstacles are overcome.

The present legislative activities promise some limited progress in this regard: The UCITS directive is in the process of modernisation. ${ }^{8}$ If these changes take effect problems with the restricted UCITS definition in regard to money market funds, "funds of funds" and index funds will be overcome. The adjustments will further introduce a fully harmonised simplified prospectus alleviating the fixed cost problem of entering another EU market.

The Lamfalussy approach to financial market legislation (the establishment of a 4 level regulatory approach, see LAMFALUSSY REPORT, 2001) is also relevant in the UCITS context. If the new procedures prove to be successful in speeding up legislation this could shorten time lags between fund market developments and UCITS directives. The ongoing adjustments are an impressive example for the slow reaction speed: The two initiatives to modernise the fund directive date back to summer 1998 and will not pass before the end of 2001.

Less progress is made concerning the problem of host country control in regard to advertising. In particular, the e-Commerce Directive ${ }^{9}$ will not help the fund industry

$8 \operatorname{COM}(2000) 329$ and COM (2000) 331.

9 Directive 2000/31/EC. 
to overcome national borders through the Internet (FEFSI, 2001c): Although the spirit of the e-Commerce Directive is to establish the country of origin approach in the regulation of a server, a derogation concerns the host country control in the marketing of UCITS. Thus, the EU fund industry remains confronted with the problem that each pan-European marketing strategy can be challenged by national authorities in each EU member countries on grounds of consumer protection.

In regard to discriminatory fund tax practices there is hardly any progress. The Code of Conduct for Business Taxation is not helpful to overcome the UCITS problems. The Code of Conduct addresses tax practices aimed at attracting foreign business to a Member State rather than measures of keeping foreign business out of a market which is the problem in the fund market (FEFSI and PRICEWATERHOUSE COOPERS, 2001). At least for some countries like Denmark all other attempts to open the country for foreign funds will be in vain as long as the most serious forms of tax discrimination are not abolished.

So far European legislator have not addressed a further topic which might be promising given the above insights on distribution linked obstacles: Pressing fund distributors to behave less biased in selling funds. Of course, it is not easy to design measures that could foster more neutral fund selection. The problem is that substantial additional regulatory costs must be avoided since these are not in the interest of the consumers. Nevertheless, given the large relevance of the distribution obstacle for the fragmentation of fund markets legislators should devote more thoughts and efforts to this issue.

\section{References}

FEFSI (2001a), The State of the European Investment Funds Industry, Brussels 2001, download: www.fefsi.org.

FEFSI (2001b), Quarterly Statistical Release, No. 6, September 2001, Brussels, download: www.fefsi.org.

FEFSI (2001c), Annual Report 2000-2001, Brussels, download: www.fefsi.org.

FEFSI and PrICEWATERHOUSE COOPERS (2001), Discriminatory Tax Barriers in the Single European Investment Funds Market: a Discussion Paper, Report to the European Investment Funds Industry, London, June 2000, download: www.fefsi.org.

HERRING, FrANK (2001), European Licence for all Funds?, in: Vision + Money Special, The Financial Markets Magazine of Deutsche Börse AG, October 2001, 26-30.

ICI (2000), Investment Company Institute: Questionnaire Response to Committee of Wise Men on the Regulation of European Securities markets, download: www.ici.org/eu_ucits_wise_com.html. 
LAmFAluSsy Report (2001), Final Report of the Committee of Wise Men on the Regulation of European Securities Markets, Brussels, 15 February 2001.

MackAy, DiAna (2001), Mutual Funds Trends and Developments, Presentation ICI General Members Meeting, May 2001.

Moody's InVestors SERVice (2000), Moody's Global Fund Update: Cross-Border Distribution of Funds - Hurdles and Developments, August 2000.

SEC (2000), US Securities and Exchange Commission, Division of Investment Management: Report on Mutual Fund Fees and Expenses, Washington 2000, download: www.sec.gov/news/studies/feestudy.htm.

WARLAND, PhiliP (2002), European Fund Opportunities - Not for the Fainthearted, JP Morgan Chase client publication, London. 